Asian J. Med. Biol. Res. 2021, 7 (1), 12-20; doi: 10.3329/ajmbr.v7i1.53304

\author{
Asian Journal of \\ Medical and Biological Research \\ ISSN 2411-4472 (Print) 2412-5571 (Online) \\ www.ebupress.com/journal/ajmbr
}

\title{
Article \\ Physico-chemical properties of acid soils from Madhupur Tract and Northern \& Eastern Piedmont Plains of Bangladesh
}

\author{
Asif Ahmed Ratul, Tahsina Sharmin Hoque, Md. Rafiqul Islam and Md. Anamul Hoque \\ Department of Soil Science, Bangladesh Agricultural University, Mymensingh-2202, Bangladesh \\ ${ }^{*}$ Corresponding author: Dr. Tahsina Sharmin Hoque, Professor, Department of Soil Science, Bangladesh \\ Agricultural University, Mymensingh-2202, Bangladesh. Phone: +8801720450650; E-mail: \\ tahsinasharmin@bau.edu.bd
}

Received: 07 February 2021/Accepted: 16 March 2021/ Published: 31 March 2021

\begin{abstract}
Soil reaction is an important issue that adversely affects soil fertility and crop productivity. Twenty five representative soil samples from farmers' fields of Ramchandrakura, Bishgiripar, Andharupara and Nayabil villages of Nalitabari upazila under Sherpur district (AEZ 22-Northern and Eastern Piedmont Plains) and twenty soil samples from farmers' fields of Bakta, Nishchintopur, Boril and Kaladaho villages of Fulbaria upazila under Mymensingh district (AEZ 28-Madhupur Tract) were collected and analyzed to study the physicochemical properties of acid soils. Among 45 samples, 13 were sandy loam, 17 were silt loam, 10 were loam, 2 were clay loam and 3 were loamy sand in texture. Soil $\mathrm{pH}$ was very strongly acidic to strongly acidic. The soil $\mathrm{pH}$ of AEZ 22 varied from 3.81 to 4.78 and that of AEZ 28 varied from 3.96 to 5.11. The organic $\mathrm{C}$ of Nalitabari soil varied from 0.50 to $1.35 \%$ and that of Fulbaria soils ranged from 0.50 to $1.27 \%$ showing low to medium status. The status of nutrient elements viz. N, P, K and S in most of the samples was very low or very low to medium. Total $\mathrm{N}$ contents of AEZ 22 varied from 0.06 to $0.14 \%$ and that of AEZ 28 varied from 0.07 to $0.16 \%$. Available P in soils of AEZ 22 varied from 3.25 to $26.45 \mathrm{ppm}$ and that in soils of AEZ 28 ranged from 2.45 to $16.62 \mathrm{ppm}$. Exchangeable K in AEZ 22 soils varied from 15.13 to $92.41 \mathrm{ppm}$ and that in AEZ 28 soils varied from 16.09 to $98.41 \mathrm{ppm}$. Available S in AEZ 22 soils varied from 1.68 to $33.70 \mathrm{ppm}$ and that in AEZ 28 soils from 3.95 to $27.52 \mathrm{ppm}$. Therefore, these acid soils should be amended with liming materials and fertilized with inorganic fertilizers and organic manures for successful crop production.
\end{abstract}

Keywords: acid soils; agroecological zones; soil pH; textural class; nutrient status

\section{Introduction}

Bangladesh is an agro-based country where soil classifications and their using patterns are major concerns for researchers as well as the farmers to feed the future. Bangladesh has a wider range and greater complexity of lands. The entire country is formed by sediments ranging in age from recent to tertiary. Three major physiographic units are recognized in Bangladesh on the basis of landforms and geology: a) Northern and Eastern Hills of Tertiary formation, occupying $12 \%$ of the total area; b) Pleistocene Terraces of Madhupur and Barind Tracts occupying $8 \%$ of the total area; and c) Recent Floodplains covering the rest $80 \%$ of the total area (Brammer, 1996; Huq and Shoaib, 2013; Islam et al., 2017). Based on the mode of formation and morphological appearance, soils are grouped into 21 General Soil Types, which are correlated with the USDA Taxonomy and FAO-UNESCO classification systems (Shaheed, 1984; Moslehuddin et al., 1997). There are 30 agro-ecological regions (AEZs), 88 sub-regions and 535 agro-ecological units identified in Bangladesh (FAO-UNDP, 1988). The present study area named Madhupur Tract is enlisted as 28th AEZ of Bangladesh which occupies an area of 42,4359 ha and is located in the districts of Dhaka, Gazipur, Narsingdi, Narayanganj, Tangail, Jamalpur, and Mymensingh (FRG, 2018). This is a region of complex relief and soils developed over the Madhupur Clay. The tract is also crossed by a number of rivers which has either old or young Brahmaputra alluvium on their 
floodplains, leaving small hillocks of red soils as "island" surrounded by floodplain soils. There are eleven General Soil Types occur in this region of which Deep Red-Brown Terrace soils, Brown Mottled Terrace soils and Deep Grey Terrace soils are predominant. Another study area named Northern and Eastern Piedmont Plains is enlisted as 22th AEZ of Bangladesh which occupies an area of 40,3758 ha and is located in the districts of Netrokona, Sunamganj, Sherpur, Sylhet, Habiganj, Mymensingh, Moulvibazar, Comilla and B. Baria (FRG, 2018). This is a discontinuous region occurring as a narrow strip of land at the foot of the northern and eastern hills. Grey piedmont soils and non- calcareous grey floodplain soils are the major general soil types of this area. Soils of this area are loams to clays, slightly acidic to strongly acidic in reaction and fertility level is generally low to medium.

Though Bangladesh is an agrarian country, the yields of different crops are low as compared to those of other developing countries. A number of constraints including land degradation, low soil fertility, nutrient mining and poor management practices are responsible for this. Land degradation is a major threat to food and environment security of Bangladesh. In this regard, acid soil is an important issue because of its adverse effects on nutrient availability and crop productivity. Geomorphologically, acid sulphate soils, peat soils, acid basin clays, terrace soils, piedmont soils and hill soils are slightly to strongly acidic in reaction. Considering 30 AEZs of Bangladesh, acid soils occur in Old Himalayan Piedmont Plain (AEZ 1), Lower Purnabhaba Floodplain (AEZ 6), Ganges Tidal Floodplain (AEZ 13) containing acid sulphate soils, Gopalganj- Khulna Bils (AEZ 14) containing peat soils, Arial Bil (AEZ 15), Sylhet Basin (AEZ 21), Northern and Eastern Piedmont Plains (AEZ 22), Chittagong Coastal Plains (AEZ 23) having acid sulphate soils, Level Barind Tract (AEZ 25), North Eastern Barind Tract (AEZ 27), Madhupur Tract (AEZ 28) and Northern and Eastern Hills (AEZ 29). It is estimated that soils of 0.25 Mha of lands across the country are very strongly acidic $(\mathrm{pH}<4.5), 3.71$ Mha of lands are strongly acidic ( $\mathrm{pH} 4.5-5.5)$, and 2.74 Mha of lands are slightly acidic (pH 5.6-6.5) in reaction (SRDI, 2010). Acid soils are widespread in Bangladesh which may constraint major crop production in more than $30 \%$ of lands (FRG, 2018). Acid soils possess toxic concentrations of $\mathrm{Al}^{3+}, \mathrm{Fe}^{3+}$ and $\mathrm{Mn}^{2+}$, lower concentrations of $\mathrm{P}$ and low availability of bases which together cause reduction in crop yield. Soil acidification may intensify and affect crop production if effective management strategies for amelioration are not implemented. Optimum crop growth and efficient use of fertilizer in acid soils require an addition of lime to eliminate the toxic effects of acid cations. For proper land use, classification and its patterns, future agricultural planning and ways of management of soils, it is important to know the status of physical and chemical properties of acid soils. Sporadic works have been conducted on different AEZs and some soil series of Bangladesh. However, sufficient data and in-depth analysis are not available on acid soils in Madhupur Tract and Northern \& Eastern Piedmont Plains of Bangladesh. Therefore, the present study was conducted to evaluate general characteristics of soils in two acid prone AEZs (22 and 28) of Bangladesh for improving soil fertility status and to suggest suitable recommendation for adopting different management practices at farmers' level.

\section{Materials and Methods}

\subsection{Site selection}

The sites for acid soils cover two AEZs of the country namely Northern \& Eastern Piedmont Plains (AEZ 22) and Madhupur Tract (AEZ 28) including two upazilas (Nalitabari and Fulbaria) and eight villages.

\subsection{Soil sample collection and preparation}

A total of forty five samples were collected from two AEZs representing terrace soils of intensively cropped areas. For AEZ 22, the selected villages were Ramchandrakura (7 samples), Bishgiripar (6 samples), Andharupara (6 samples) and Nayabil (6 samples). On the other hand, for AEZ 28 the selected villages were Bakta (5 samples), Nishchintopur (5 samples), Boril (5 samples) and Kaladaho (5 samples). The sampling depth was 0 to $15 \mathrm{~cm}$ for all cases. The collected soil samples were carried to the laboratory for physical and chemical analysis. The samples were air-dried at room temperature, mixed thoroughly, crushed, sieved through a 20-mesh sieve and preserved in plastic bags for subsequent laboratory analysis. The analysis part of experiment was carried out at the Department of Soil Science, Bangladesh Agricultural University, Mymensingh.

\subsection{Particle size analysis}

Particle size analysis of soil was carried out by hydrometer method as described by Bouyoucos (1962). For each sample, fifty gram of oven dry soil was taken in dispersion cup and $10 \mathrm{~mL}$ of $5 \%$ calgon solution was added to the sample. After soaking the sample with water, the suspension was stirred with an electrical stirrer and transferred to sedimentation cylinder for sedimentation. The hydrometer readings were taken at 40 seconds and at 2 hours of sedimentation. 
The percentage of sand, silt and clay were calculated as follow:

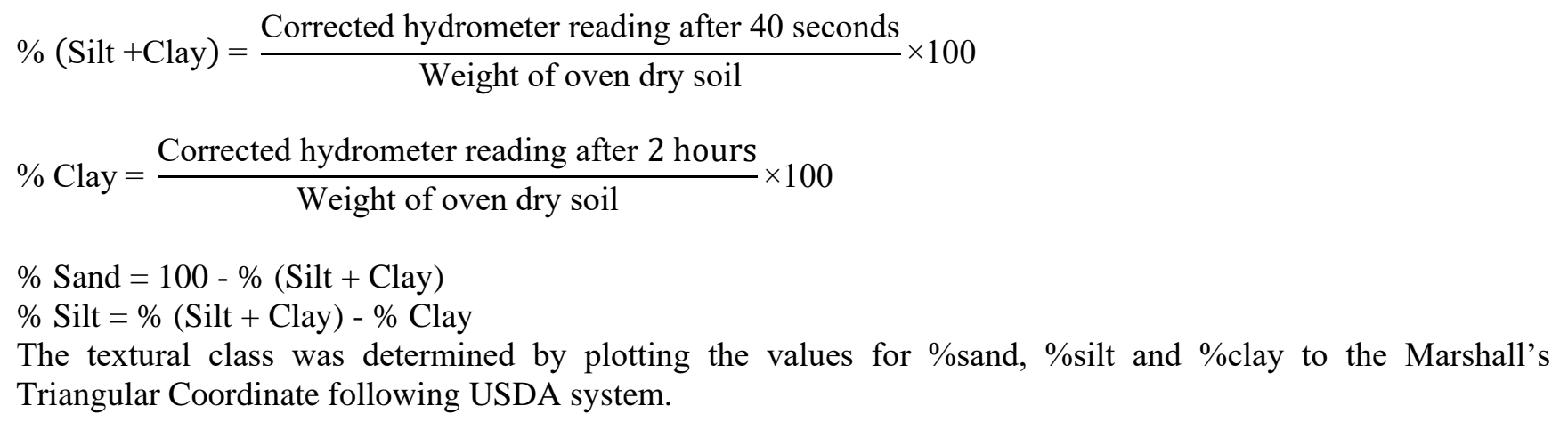

\subsection{Soil pH}

The $\mathrm{pH}$ of soil was determined electrochemically with the help of a glass-electrode $\mathrm{pH}$ meter in the soil suspension having a soil: water ratio of 1:2.5 after 30 minutes shaking as described by Jackson (1962).

\subsection{Organic carbon}

Organic carbon of soil was determined by wet oxidation method of Walkey and Black (1934). The underlying principle was to oxidize the organic matter of soil with an excess of $\mathrm{N} \mathrm{K}_{2} \mathrm{Cr}_{2} \mathrm{O}_{7}$ in presence of conc. $\mathrm{H}_{2} \mathrm{SO}_{4}$ and conc. $\mathrm{H}_{3} \mathrm{PO}_{4}$ and to titrate the residual $\mathrm{K}_{2} \mathrm{Cr}_{2} \mathrm{O}_{7}$ solution with $\mathrm{N} \mathrm{FeSO}_{4}$. Organic carbon of soil was calculated by using the following formula:

$\%$ Organic carbon $=\frac{\mathrm{V}_{1}-\left(\mathrm{V}_{2} \times \mathrm{N}\right)}{\mathrm{W}} \times 0.003 \times 1.3 \times 100$

Where,

$$
\begin{aligned}
& \mathrm{V}_{1}=\text { Vol. of } \mathrm{N} \mathrm{K}_{2} \mathrm{Cr}_{2} \mathrm{O}_{7} \text { solution } \\
& \mathrm{V}_{2}=\text { Vol. of } \mathrm{XN} \mathrm{FeSO}_{4} \text { solution } \\
& \mathrm{N}=\text { Normality of } \mathrm{FeSO}_{4} \text { solution } \\
& \mathrm{W}=\text { Wt. of soil taken and } \\
& 1.3=\text { Conventional recovery factor } \\
& 1 \mathrm{~mL} \text { of } 1 \mathrm{~N} \mathrm{~K}_{2} \mathrm{Cr}_{2} \mathrm{O}_{7} \equiv 0.003 \mathrm{~g} \text { of carbon }
\end{aligned}
$$

\subsection{Total nitrogen}

Total nitrogen content in soil was determined by semi micro-Kjeldhal method (Bremner and Mulvancy, 1982). Digestion was made using $1 \mathrm{~g}$ soil with $2 \mathrm{~mL} 30 \% \mathrm{H}_{2} \mathrm{O}_{2}, 3 \mathrm{~mL}$ conc. $\mathrm{H}_{2} \mathrm{SO}_{4}$ and $1.1 \mathrm{~g}$ catalyst mixture $\left(\mathrm{K}_{2} \mathrm{SO}_{4}\right.$ : $\left.\mathrm{CuSO}_{4} .5 \mathrm{H}_{2} \mathrm{O}: \mathrm{Se}=100: 10: 1\right)$. Nitrogen in the digest was estimated by distillation with $40 \% \mathrm{NaOH}$ followed by titration of the distillate trapped in $\mathrm{H}_{3} \mathrm{BO}_{3}$ with $0.01 \mathrm{~N} \mathrm{H}_{2} \mathrm{SO}_{4}$. The amount of $\mathrm{N}$ was calculated using the following formula:

$$
\% \mathrm{~N}=\frac{(\mathrm{T}-\mathrm{B}) \times \mathrm{N} \times 0.014 \times 100}{\mathrm{~S}}
$$

Where,

$\mathrm{T}=$ Sample titration value $(\mathrm{mL})$ of standard $\mathrm{H}_{2} \mathrm{SO}_{4}$

$\mathrm{B}=$ Blank titration value $(\mathrm{mL})$ of standard $\mathrm{H}_{2} \mathrm{SO}_{4}$

$\mathrm{N}=$ Strength of $\mathrm{H}_{2} \mathrm{SO}_{4}$

$\mathrm{S}=$ Weight of soil sample in gram

\subsection{Available phosphorus}

Available $\mathrm{P}$ was extracted from the soil samples by shaking with $0.5 \mathrm{M} \mathrm{NaHCO}_{3}$ solution at $\mathrm{pH} 8.5$ following Olsen method (Olsen et al., 1954). The extracted $\mathrm{P}$ was determined by developing blue color by $\mathrm{SnCl}_{2}$ reduction of phosphomolybdate complex and measuring the intensity of color spectrophotometrically at $660 \mathrm{~nm}$ wavelength and the readings were calibrated to the standard $\mathrm{P}$ curve. 
2.8. Exchangeable potassium

Exchangeable $\mathrm{K}$ was extracted from the soil samples with $1.0 \mathrm{~N} \mathrm{NH}_{4} \mathrm{OAc}(\mathrm{pH} 7)$ and $\mathrm{K}$ was determined from the extract by a flame photometer (Knudsen et al., 1982) and calibrated with a standard curve.

\subsection{Available sulphur}

Available sulphur was extracted from the soil samples with $\mathrm{CaC1}_{2}$ solution $(0.15 \%)$ as described by Williams and Steinbergs (1959). The S content in the extract was estimated turbidimetrically with a spectrophotometer at $420 \mathrm{~nm}$ wavelength.

\subsection{Statistical analysis}

The data of soil analysis were adjudged statistically using mean and standard deviation following the MSTATcomputer package program as suggested by Russel (1986).

\section{Results and Discussion}

\subsection{Soil texture}

The results on particle size distribution of soils are presented in Table 1. Among 45 soil samples, 17 were silt loam, 13 were sandy loam, 10 were loam, 2 were clay loam and 3 were loamy sand in texture. The textural classes of Nalitabari soils were sandy loam, loamy sand, silt loam and loam. However, the soils of Fulbaria soils were loam, silt loam, clay loam and sandy loam in texture. In general, the textural class silt loam was dominant among all the soils and this textural class is suitable for most of the agricultural crop production. In soils of AEZ 22 , the percentage of sand was higher than those of clay and silt while, the percentage of silt was higher than those of sand and clay in soils of AEZ 28. This variation in sand, silt and clay contents might be due to movement of the clay and colloidal size particle through percolated water.

\subsection{Soil pH and organic carbon}

In Nalitabari location (AEZ 22), the $\mathrm{pH}$ of soils varied from 3.81 to 4.78 suggesting the presence of very strongly acid soils in the region (Table 2). Among the different soils of this AEZ, the soil pH of Ramchandrakura village ranged from 4.18-4.78, Bishgiripar village ranged from 3.81-4.12, Andharupara village ranged from 3.88-4.13 and Nayabil village ranged from 3.93-4.47. The highest value of soil $\mathrm{pH}$ (4.78) was observed in Ramchandrakura-2 and the lowest value of soil pH (3.81) was observed in Bishgiripar-5. In Fulbaria location (AEZ 28), the $\mathrm{pH}$ of soils varied from 3.96 to 5.11 suggesting the presence of very strongly to moderately acidic soils in the region (Table 2). Among different soil samples of this AEZ, the soil pH of Bakta village ranged from 4.54-4.89, Nishchintopur village ranged from 3.96-4.56, Boril village ranged from 4.624.97 and Kaladaho village ranged from 4.43-5.11. The highest value of soil pH (5.11) was observed in Kaladaho-4and the lowest value of soil $\mathrm{pH}$ (3.96) was observed in Nishchintopur-4. There was no significant difference in $\mathrm{pH}$ values between AEZ 22 (Northern and Eastern Piedmont Plain) and AEZ 28 (Madhupur Tract). Strongly acidic soil in AEZ 22 and 28 was also found by Shil et al. 2016. Most of the chemical and nutritional properties of soils are regulated by soil $\mathrm{pH}$. Excessive acidity is detrimental to soil health which increases soil toxicity and fixation of nutrient elements (Hart et al., 2013). As pH of all these 45 soil samples were <5.5, lime application is necessary for successful crop production. Lime addition is crucial because liming of acid soils changes the $\mathrm{pH}$, rectifies adverse effects of acid cations and also improves the soil fertility (Reddy and Subramanian, 2016).

The organic $\mathrm{C}$ content of soil samples of Nalitabari location (AEZ 22) varied from 0.50 to $1.35 \%$ (Table 2). Among the different soils of this AEZ, the organic C of Ramchandrakura village ranged from 0.62-0.93\%, Bishgiripar village ranged from 0.50-1.00\%, Andharupara village ranged from 0.77-0.93\% and Nayabil village ranged from $0.73-1.35 \%$. The highest content of organic C (1.35\%) was observed in Nayabil-4 and the lowest content of organic carbon $(0.50 \%)$ was observed in Bishgiripar-1. On the other hand, in Fulbaria location (AEZ 28 ), the organic $\mathrm{C}$ content of 20 soil samples varied from $0.50-1.27 \%$. Among different soil samples of this AEZ, the organic $\mathrm{C}$ of Bakta village ranged from 0.58-1.27\%, Nishchintopur village ranged from $0.62-1.24 \%$, Boril village ranged from $0.50-1.27 \%$ and Kaladaho village ranged from 0.85-1.24\%. The highest organic carbon content $(1.27 \%)$ was observed in Bakta-5 and Boril-2 and the lowest organic C content $(0.50 \%)$ was observed in Boril-5. In general, the organic $\mathrm{C}$ contents of the studied acid soils were low to medium (FRG, 2018). Carbon is a vital element that accomplishes all bio-physico-chemical properties in soils (Islam et al., 2018). Depletion of soil organic $C$ and its fertility has been recognized as one of the major causes that hinder crop production in Bangladesh. Use of available organic materials such as poultry manure, cow dung, green 
manure, household wastes, rice straw and other crop residues, etc. can increase $\mathrm{C}$ contents in soils which might contribute in improving soil health and ensuring sustainability of crop production in the studied area.

\subsection{Total nitrogen and available phosphorus}

The total N content of 45 soil samples collected from Northern and Eastern Piedmont Plains and Madhupur Tract are presented in Table 3. In Nalitabari location (AEZ 22), the total $\mathrm{N}$ content of 25 soil samples varied from 0.06 to $0.14 \%$. Among the different soils of this AEZ, the total $\mathrm{N}$ contents of Ramchandrakura village ranged from $0.07-0.12 \%$, Bishgiripar village ranged from 0.06-0.10\%, Andharupara village ranged from 0.07$0.11 \%$ and Nayabil village ranged from $0.07-0.14 \%$. The maximum total $\mathrm{N}$ content $(0.14 \%)$ was observed in Nayabil-6 and the lowest $\mathrm{N}$ content $(0.06 \%)$ was observed in Bishgiripar-1. On the other hand, in Fulbaria location (AEZ 28), the total $\mathrm{N}$ content of 20 soil samples varied from 0.07 to $0.16 \%$. Among different soil samples of this AEZ, the total $\mathrm{N}$ content of Bakta village ranged from 0.07-0.13\%, Nishchintopur village ranged from $0.08-0.14 \%$, Boril village ranged from $0.08-0.14 \%$ and Kaladaho village ranged from $0.10-0.16 \%$. The highest total $\mathrm{N}$ content $(0.16 \%)$ was observed in Kaladaho- 2 and the lowest $\mathrm{N}$ content $(0.07 \%)$ was observed in Bakta-1. In general, the content of total $\mathrm{N}$ of Nalitabari soils (Northern and Eastern Piedmont Plains) and Fulbaria soils (Madhupur Tract) were almost similar and the status was low to medium as per BARC ratings (FRG, 2018).

The results presented in Table 3 also indicate that the amount of available $\mathrm{P}$ varied markedly from soil to soil and from location to location. In Nalitabari location (AEZ 22), the available P of soils varied from 3.25 to 26.45 ppm. Among the different soils of this AEZ, the available P content of Ramchandrakura village ranged from 6.57-15.63 ppm, Bishgiripar village ranged from 3.25-26.45 ppm, Andharupara village ranged from 3.26-16.32 ppm and Nayabil village ranged from 4.24-25.19 ppm. The highest available $\mathrm{P}$ content $(26.45 \mathrm{ppm})$ was observed in Bishgipar-5 and the lowest $\mathrm{P}$ content $(3.25 \mathrm{ppm})$ was recorded in Bishgiripar-6. In Nalitabari location ( 25 samples), the available $\mathrm{P}$ status of 21 samples was very low to medium, 1 sample was optimum and 3 samples was high. On the other hand, in Fulbaria location (AEZ 28), the available P of soils varied from 2.45 to $16.62 \mathrm{ppm}$. Among different soil samples of this AEZ, the available P content of Bakta village ranged from 6.71-16.62 ppm, Nishchintopur village ranged from 2.45-7.46 ppm, Boril village ranged from 4.35-10.61 ppm and Kaladaho village ranged from 5.34-11.79 ppm. The maximum available P content (16.62 ppm) was observed in Bakta-1 and the minimum available P (2.45 ppm) was noted in Nishchintopur-5. Out of 20 samples, the available P status of 19 samples was very low to low but only one sample (Bakta-1) had medium P status. In general, the available P content of AEZ 22 was a bit higher than that of AEZ 28. Again, among 45 soil samples, only 18 soil samples had higher amount of available $\mathrm{P}$ than the critical level of $8 \mathrm{ppm}$ as determined by Olsen method. Moslehuddin et al. (1997) reported deficiency of available P in acidic soils of terrace and hilly areas of Bangladesh where a sharp response of added $\mathrm{P}$ was found because $\mathrm{P}$ is readily fixed in acidic soils by reaction with Fe and Al.

\subsection{Exchangeable potassium and available sulphur}

The exchangeable $\mathrm{K}$ content of 45 soil samples collected from Northern and Eastern Piedmont Plains and Madhupur Tract have been presented in Table 4. The amount of exchangeable K differed from soil to soil and from location to location. In Nalitabari location, the exchangeable K content of soils varied from 15.13 to 92.41 ppm. Among different soils of this AEZ, the exchangeable K contents of Ramchandrakura village ranged from 15.13-38.57 ppm, Bishgiripar village ranged from 15.14-45.55 ppm, Andharupara village ranged from 16.74$61.18 \mathrm{ppm}$ and Nayabil village ranged from $25.71-92.41 \mathrm{ppm}$ with the highest value in Nayabil-5 and the lowest value in Ramchandrakura-7. On the other hand, in Fulbaria location, the exchangeable K content of soils ranged from 16.09 to $98.41 \mathrm{ppm}$ (Table 4). Among the samples, the exchangeable K contents of Bakta village ranged from 16.09-28.77 ppm, Nishchintopur village ranged from 20.91-98.41 ppm, Boril village ranged from 20.04$28.81 \mathrm{ppm}$ and Kaladaho village ranged from 22.90-33.62 ppm with the maximum value in Nishchintopur-2 and the minimum in Bakta-2. In general, the exchangeable $\mathrm{K}$ content of Nalitabari soils and Fulbaria soils were almost similar. In both of the AEZs, the exchangeable K status of most of the soils was very low. Out of 45 samples, only three soils (Nayabil-5, Nishchintopur-1 and Nishchintopur-2) had optimum K status.

The results presented in Table 4 also show that the content of available $\mathrm{S}$ varied considerably from soil to soil and from location to location. In Nalitabari location (Northern and Eastern Piedmont Plains), the available $S$ ranged from 1.68 to $33.70 \mathrm{ppm}$. Among different soils of this AEZ, the available S contents of Ramchandrakura village ranged from 1.68-26.47 ppm, Bishgiripar village ranged from 7.32-33.70 ppm, Andharupara village ranged from 6.08-35.02 ppm and Nayabil village ranged from 6.05-28.64 ppm with the highest value in Bishgiripar-3 and the lowest value in Ramchandrakura-1. On the other hand, in Fulbaria location (Madhupur 
Tract), the available $S$ content of soils varied from 3.95 to $27.02 \mathrm{ppm}$. In this AEZ, the available $S$ contents of Bakta village ranged from 3.95-23.52 ppm, Nishchintopur village ranged from 8.13-27.02 ppm, Boril village ranged from 7.93-25.03 ppm and Kaladaho village ranged from 8.73-12.93 ppm with the maximum value in Nishchintopur-5 and the minimum value in Bakta-2. In general, among 45 soil samples, 26 soil samples showed higher amount of available $\mathrm{S}$ than the critical level of $10 \mathrm{ppm}$ as determined by $\mathrm{CaCl}_{2}$ extraction method and other 19 soil samples showed lower amount of available $\mathrm{S}$. The range of available $\mathrm{S}$ status was found very low to optimum in AEZ 22 and very low to medium in AEZ 28 (FRG, 2018).

Portch and Islam (1984) in their study showed that many soils from different regions of Bangladesh are declining in fertility status and some of them even containing nutrient elements below the critical levels. Poor status of essential nutrient elements such as organic $\mathrm{C}$, total $\mathrm{N}$, available $\mathrm{P}$, exchangeable $\mathrm{K}$ and available $\mathrm{S}$ might be due to low soil $\mathrm{pH}$, imbalanced application of chemical fertilizers, higher removal of nutrients by HYV crops and lack of incorporation of crop residues and organic materials in soil (Islam, 2008; Kumar et al. 2019). Besides lime application, sustainable agricultural approaches such as mixed farming systems, integrated nutrient management, more use of organic manures, crop rotation, recycling crop residue and animal wastes, intercropping, multi-cropping, cover crops, etc. should be adopted to improve fertility status of these soils.

Table 1. Particle size distribution and textural classes of the soils under study.

\begin{tabular}{|c|c|c|c|c|c|c|c|c|c|}
\hline \multicolumn{5}{|c|}{ Nalitabari upazila } & \multicolumn{5}{|c|}{ Fulbaria upazila } \\
\hline \multirow[t]{2}{*}{ Soils } & \multicolumn{3}{|c|}{ Particle size } & \multirow{2}{*}{$\begin{array}{l}\text { Textural } \\
\text { class }\end{array}$} & \multirow[t]{2}{*}{ Soils } & \multicolumn{3}{|c|}{ Particle size } & \multirow{2}{*}{$\begin{array}{l}\text { Textural } \\
\text { class }\end{array}$} \\
\hline & $\%$ Sand & $\%$ Silt & \% Clay & & & \%Sand & $\%$ Silt & \% Clay & \\
\hline Ramchandrakura-1 & 58 & 32 & 10 & Sandy loam & Bakta-1 & 42 & 48 & 10 & Loam \\
\hline Ramchandrakura-2 & 62 & 32 & 6 & Sandy loam & Bakta-2 & 40 & 50 & 10 & Silt loam \\
\hline Ramchandrakura-3 & 72 & 26 & 2 & Sandy loam & Bakta-3 & 40 & 54 & 6 & Silt loam \\
\hline Ramchandrakura-4 & 66 & 30 & 4 & Sandy loam & Bakta-4 & 40 & 52 & 8 & Silt loam \\
\hline Ramchandrakura-5 & 70 & 28 & 2 & Sandy loam & Bakta-5 & 40 & 54 & 6 & Silt loam \\
\hline Ramchandrakura-6 & 76 & 20 & 4 & Loamy sand & Nishchintopur-1 & 38 & 56 & 6 & Silt loam \\
\hline Ramchandrakura-7 & 78 & 18 & 4 & Loamy sand & Nishchintopur-2 & 40 & 50 & 10 & Silt loam \\
\hline Bishgiripar-1 & 70 & 26 & 4 & Sandy loam & Nishchintopur-3 & 40 & 52 & 8 & Silt loam \\
\hline Bishgiripar-2 & 60 & 34 & 6 & Sandy loam & Nishchintopur-4 & 40 & 50 & 10 & Silt loam \\
\hline Bishgiripar-3 & 60 & 36 & 4 & Sandy loam & Nishchintopur-5 & 38 & 52 & 10 & Silt loam \\
\hline Bishgiripar-4 & 42 & 52 & 6 & Silt loam & Boril-1 & 32 & 36 & 32 & Clay loam \\
\hline Bishgiripar-5 & 58 & 36 & 6 & Sandy loam & Boril-2 & 32 & 36 & 32 & Clay loam \\
\hline Bishgiripar-6 & 48 & 44 & 8 & Loam & Boril-3 & 36 & 48 & 16 & Loam \\
\hline Andharupara-1 & 68 & 28 & 4 & Sandy loam & Boril-4 & 38 & 54 & 8 & Silt loam \\
\hline Andharupara-2 & 62 & 32 & 6 & Sandy loam & Boril-5 & 38 & 56 & 6 & Silt loam \\
\hline Andharupara-3 & 36 & 44 & 20 & Loam & Kaladaho-1 & 38 & 54 & 8 & Silt loam \\
\hline Andharupara-4 & 40 & 42 & 18 & Loam & Kaladaho-2 & 36 & 50 & 14 & Silt loam \\
\hline Andharupara-5 & 42 & 38 & 20 & Loam & Kaladaho-3 & 38 & 56 & 6 & Silt loam \\
\hline Andharupara-6 & 44 & 46 & 10 & Loam & Kaladaho-4 & 44 & 50 & 6 & Silt loam \\
\hline Nayabil-1 & 38 & 38 & 24 & Loam & Kaladaho-5 & 54 & 44 & 2 & Sandy loam \\
\hline Nayabil-2 & 40 & 42 & 18 & Loam & - & - & - & - & - \\
\hline Nayabil-3 & 44 & 40 & 16 & Loam & - & - & - & - & - \\
\hline Nayabil-4 & 42 & 40 & 18 & Loam & - & - & - & - & - \\
\hline Nayabil-5 & 72 & 24 & 4 & Sandy loam & - & - & - & - & - \\
\hline Nayabil-6 & 36 & 50 & 14 & Silt loam & - & - & - & - & - \\
\hline
\end{tabular}

Data are means of three replicates 
Table 2. pH and organic carbon contents of the soils under study.

\begin{tabular}{|c|c|c|c|c|c|}
\hline \multicolumn{3}{|c|}{ Nalitabari upazila } & \multicolumn{3}{|c|}{ Fulbaria upazila } \\
\hline Soils & pH & Organic C (\%) & Soils & pH & Organic C (\%) \\
\hline Ramchandrakura-1 & $4.66 \pm 0.06$ & $0.89 \pm 0.14$ & Bakta-1 & $4.54 \pm 0.17$ & $1.04 \pm 0.01$ \\
\hline Ramchandrakura-2 & $4.78 \pm 0.03$ & $0.77 \pm 0.01$ & Bakta-2 & $4.62 \pm 0.08$ & $0.85 \pm 0.03$ \\
\hline Ramchandrakura-3 & $4.42 \pm 0.14$ & $0.85 \pm 0.04$ & Bakta-3 & $4.89 \pm 0.13$ & $0.58 \pm 0.01$ \\
\hline Ramchandrakura-4 & $4.53 \pm 0.10$ & $0.93 \pm 0.01$ & Bakta-4 & $4.60 \pm 0.14$ & $0.77 \pm 0.01$ \\
\hline Ramchandrakura-5 & $4.42 \pm 0.11$ & $0.93 \pm 0.01$ & Bakta-5 & $4.59 \pm 0.13$ & $1.27 \pm 0.01$ \\
\hline Ramchandrakura-6 & $4.18 \pm 0.11$ & $0.62 \pm 0.01$ & Nishchintopur-1 & $4.52 \pm 0.09$ & $0.73 \pm 0.01$ \\
\hline Ramchandrakura-7 & $4.23 \pm 0.14$ & $0.62 \pm 0.01$ & Nishchintopur-2 & $4.56 \pm 0.06$ & $0.73 \pm 0.01$ \\
\hline Bishgiripar-1 & $4.12 \pm 0.17$ & $0.50 \pm 0.01$ & Nishchintopur-3 & $4.31 \pm 0.12$ & $0.73 \pm 0.01$ \\
\hline Bishgiripar-2 & $3.98 \pm 0.03$ & $0.81 \pm 0.02$ & Nishchintopur-4 & $3.96 \pm 0.06$ & $0.62 \pm 0.01$ \\
\hline Bishgiripar-3 & $4.11 \pm 0.08$ & $1.00 \pm 0.01$ & Nishchintopur-5 & $4.43 \pm 0.07$ & $1.24 \pm 0.02$ \\
\hline Bishgiripar-4 & $3.99 \pm 0.04$ & $0.73 \pm 0.01$ & Boril-1 & $4.75 \pm 0.07$ & $1.08 \pm 0.03$ \\
\hline Bishgiripar-5 & $3.81 \pm 0.06$ & $0.89 \pm 0.01$ & Boril-2 & $4.97 \pm 0.05$ & $1.27 \pm 0.01$ \\
\hline Bishgiripar-6 & $4.02 \pm 0.09$ & $0.70 \pm 0.01$ & Boril-3 & $4.62 \pm 0.11$ & $1.08 \pm 0.01$ \\
\hline Andharupara-1 & $3.89 \pm 0.13$ & $0.77 \pm 0.01$ & Boril-4 & $4.92 \pm 0.11$ & $0.85 \pm 0.01$ \\
\hline Andharupara-2 & $3.88 \pm 0.03$ & $0.81 \pm 0.01$ & Boril-5 & $4.86 \pm 0.19$ & $0.50 \pm 0.01$ \\
\hline Andharupara-3 & $4.01 \pm 0.06$ & $0.93 \pm 0.01$ & Kaladaho-1 & $4.63 \pm 0.04$ & $1.24 \pm 0.05$ \\
\hline Andharupara-4 & $4.13 \pm 0.04$ & $0.81 \pm 0.02$ & Kaladaho-2 & $4.68 \pm 0.11$ & $1.00 \pm 0.06$ \\
\hline Andharupara-5 & $4.12 \pm 0.10$ & $0.81 \pm 0.01$ & Kaladaho-3 & $4.43 \pm 0.13$ & $1.08 \pm 0.01$ \\
\hline Andharupara-6 & $4.11 \pm 0.16$ & $0.85 \pm 0.01$ & Kaladaho-4 & $5.11 \pm 0.16$ & $0.85 \pm 0.01$ \\
\hline Nayabil-1 & $3.96 \pm 0.06$ & $1.00 \pm 0.01$ & Kaladaho-5 & $4.48 \pm 0.11$ & $0.85 \pm 0.03$ \\
\hline Nayabil-2 & $4.10 \pm 0.07$ & $0.81 \pm 0.01$ & - & - & - \\
\hline Nayabil-3 & $3.99 \pm 0.04$ & $0.85 \pm 0.01$ & - & - & - \\
\hline Nayabil-4 & $3.93 \pm 0.04$ & $1.35 \pm 0.03$ & - & - & - \\
\hline Nayabil-5 & $4.47 \pm 0.10$ & $0.73 \pm 0.01$ & - & - & - \\
\hline Nayabil-6 & $4.26 \pm 0.09$ & $1.24 \pm 0.01$ & - & - & - \\
\hline
\end{tabular}

Data are means \pm standard deviation of three replicates

Table 3. Total nitrogen and available phosphorus contents of the soils under study.

\begin{tabular}{|c|c|c|c|c|c|}
\hline \multicolumn{3}{|c|}{ Nalitabari upazila } & \multicolumn{3}{|c|}{ Fulbaria upazila } \\
\hline Soils & Total N (\%) & Available P (ppm) & Soils & Total N (\%) & Available P (ppm) \\
\hline Ramchandrakura-1 & $0.12 \pm 0.02$ & $6.90 \pm 2.01$ & Bakta-1 & $0.07 \pm 0.01$ & $16.62 \pm 2.16$ \\
\hline Ramchandrakura-2 & $0.07 \pm 0.01$ & $6.57 \pm 2.16$ & Bakta-2 & $0.08 \pm 0.01$ & $7.74 \pm 1.95$ \\
\hline Ramchandrakura-3 & $0.10 \pm 0.01$ & $12.70 \pm 2.00$ & Bakta-3 & $0.08 \pm 0.01$ & $7.68 \pm 2.01$ \\
\hline Ramchandrakura-4 & $0.12 \pm 0.01$ & $15.63 \pm 2.06$ & Bakta-4 & $0.13 \pm 0.02$ & $6.71 \pm 2.06$ \\
\hline Ramchandrakura-5 & $0.12 \pm 0.01$ & $7.41 \pm 2.02$ & Bakta-5 & $0.13 \pm 0.01$ & $7.78 \pm 2.01$ \\
\hline Ramchandrakura-6 & $0.08 \pm 0.01$ & $6.75 \pm 2.05$ & Nishchintopur-1 & $0.10 \pm 0.01$ & $3.96 \pm 2.00$ \\
\hline Ramchandrakura-7 & $0.07 \pm 0.20$ & $10.31 \pm 2.01$ & Nishchintopur-2 & $0.08 \pm 0.01$ & $7.46 \pm 2.07$ \\
\hline Bishgiripar-1 & $0.06 \pm 0.01$ & $6.93 \pm 2.05$ & Nishchintopur-3 & $0.10 \pm 0.01$ & $5.80 \pm 2.00$ \\
\hline Bishgiripar-2 & $0.10 \pm 0.01$ & $12.89 \pm 2.10$ & Nishchintopur-4 & $0.08 \pm 0.01$ & $5.53 \pm 2.00$ \\
\hline Bishgiripar-3 & $0.11 \pm 0.01$ & $25.73 \pm 2.06$ & Nishchintopur-5 & $0.14 \pm 0.01$ & $2.45 \pm 1.94$ \\
\hline Bishgiripar-4 & $0.09 \pm 0.01$ & $7.72 \pm 2.06$ & Boril-1 & $0.14 \pm 0.01$ & $5.47 \pm 2.04$ \\
\hline Bishgiripar-5 & $0.10 \pm 0.01$ & $26.45 \pm 2.11$ & Boril-2 & $0.13 \pm 0.01$ & $7.85 \pm 2.05$ \\
\hline Bishgiripar-6 & $0.10 \pm 0.01$ & $3.25 \pm 2.08$ & Boril-3 & $0.14 \pm 0.01$ & $6.66 \pm 2.06$ \\
\hline Andharupara-1 & $0.07 \pm 0.01$ & $3.26 \pm 2.06$ & Boril-4 & $0.13 \pm 0.01$ & $4.35 \pm 2.07$ \\
\hline Andharupara-2 & $0.08 \pm 0.01$ & $8.51 \pm 2.16$ & Boril-5 & $0.08 \pm 0.01$ & $10.61 \pm 2.05$ \\
\hline Andharupara-3 & $0.11 \pm 0.02$ & $5.56 \pm 2.15$ & Kaladaho-1 & $0.15 \pm 0.01$ & $8.28 \pm 1.97$ \\
\hline Andharupara-4 & $0.10 \pm 0.01$ & $16.32 \pm 2.12$ & Kaladaho-2 & $0.16 \pm 0.16$ & $5.34 \pm 2.11$ \\
\hline Andharupara-5 & $0.11 \pm 0.01$ & $10.47 \pm 2.03$ & Kaladaho-3 & $0.13 \pm 0.01$ & $11.79 \pm 2.08$ \\
\hline Andharupara-6 & $0.11 \pm 0.01$ & $5.47 \pm 2.22$ & Kaladaho-4 & $0.10 \pm 0.01$ & $7.51 \pm 2.02$ \\
\hline Nayabil-1 & $0.11 \pm 0.01$ & $8.51 \pm 2.02$ & Kaladaho-5 & $0.11 \pm 0.01$ & $9.54 \pm 2.08$ \\
\hline Nayabil-2 & $0.12 \pm 0.01$ & $4.24 \pm 2.05$ & - & - & - \\
\hline Nayabil-3 & $0.12 \pm 0.01$ & $9.66 \pm 2.08$ & - & - & - \\
\hline Nayabil-4 & $0.13 \pm 0.01$ & $5.31 \pm 2.09$ & - & - & - \\
\hline Nayabil-5 & $0.07 \pm 0.01$ & $25.19 \pm 2.03$ & - & - & - \\
\hline Nayabil-6 & $0.14 \pm 0.01$ & $22.63 \pm 2.17$ & - & - & - \\
\hline
\end{tabular}

Data are means \pm standard deviation of three replicates 
Table 4. Exchangeable potassium and available sulphur contents of the soils under study.

\begin{tabular}{|c|c|c|c|c|c|}
\hline \multicolumn{3}{|c|}{ Nalitabari upazila } & \multicolumn{3}{|c|}{ Fulbaria upazila } \\
\hline Soils & $\begin{array}{l}\text { Exchangeable K } \\
\text { (ppm) }\end{array}$ & $\begin{array}{l}\text { Available S } \\
\text { (ppm) }\end{array}$ & Soils & $\begin{array}{l}\text { Exchangeable K } \\
\text { (ppm) }\end{array}$ & $\begin{array}{l}\text { Available S } \\
\text { (ppm) }\end{array}$ \\
\hline Ramchandrakura-1 & $22.78 \pm 2.06$ & $1.68 \pm 1.04$ & Bakta-1 & $25.62 \pm 2.30$ & $14.16 \pm 1.04$ \\
\hline Ramchandrakura-2 & $17.25 \pm 1.75$ & $3.15 \pm 1.02$ & Bakta-2 & $16.09 \pm 2.03$ & $3.95 \pm 1.05$ \\
\hline Ramchandrakura-3 & $20.79 \pm 2.08$ & $8.92 \pm 1.02$ & Bakta-3 & $28.77 \pm 2.05$ & $23.52 \pm 1.06$ \\
\hline Ramchandrakura-4 & $38.57 \pm 2.13$ & $18.54 \pm 1.12$ & Bakta-4 & $20.05 \pm 2.02$ & $4.36 \pm 1.01$ \\
\hline Ramchandrakura-5 & $18.06 \pm 2.06$ & $6.60 \pm 1.12$ & Bakta-5 & $23.90 \pm 2.00$ & $4.45 \pm 1.03$ \\
\hline Ramchandrakura-6 & $22.83 \pm 2.10$ & $26.47 \pm 1.14$ & Nishchintopur-1 & $90.56 \pm 2.12$ & $8.57 \pm 1.03$ \\
\hline Ramchandrakura-7 & $15.13 \pm 2.02$ & $7.45 \pm 1.02$ & Nishchintopur-2 & $98.41 \pm 2.17$ & $8.13 \pm 1.02$ \\
\hline Bishgiripar-1 & $15.14 \pm 2.04$ & $22.69 \pm 1.04$ & Nishchintopur-3 & $20.91 \pm 2.10$ & $15.00 \pm 1.03$ \\
\hline Bishgiripar-2 & $25.77 \pm 2.05$ & $7.32 \pm 1.01$ & Nishchintopur-4 & $44.51 \pm 2.17$ & $11.64 \pm 1.08$ \\
\hline Bishgiripar-3 & $45.55 \pm 2.03$ & $33.70 \pm 1.05$ & Nishchintopur-5 & $32.62 \pm 2.11$ & $27.02 \pm 1.06$ \\
\hline Bishgiripar-4 & $19.07 \pm 1.97$ & $17.11 \pm 0.98$ & Boril-1 & $28.76 \pm 2.05$ & $13.70 \pm 1.11$ \\
\hline Bishgiripar-5 & $44.50 \pm 2.16$ & $25.62 \pm 1.10$ & Boril-2 & $26.81 \pm 2.01$ & $25.03 \pm 1.03$ \\
\hline Bishgiripar-6 & $20.01 \pm 2.01$ & $12.71 \pm 1.06$ & Boril-3 & $27.79 \pm 1.98$ & $7.93 \pm 1.04$ \\
\hline Andharupara-1 & $17.10 \pm 1.90$ & $16.41 \pm 1.05$ & Boril-4 & $28.81 \pm 2.12$ & $17.89 \pm 1.01$ \\
\hline Andharupara-2 & $16.74 \pm 2.04$ & $6.08 \pm 0.99$ & Boril-5 & $20.04 \pm 2.02$ & $20.02 \pm 1.01$ \\
\hline Andharupara-3 & $34.61 \pm 2.11$ & $13.91 \pm 1.10$ & Kaladaho-1 & $33.62 \pm 2.00$ & $9.53 \pm 1.06$ \\
\hline Andharupara-4 & $61.18 \pm 2.05$ & $7.79 \pm 0.59$ & Kaladaho-2 & $28.71 \pm 1.99$ & $12.09 \pm 1.02$ \\
\hline Andharupara-5 & $29.64 \pm 2.11$ & $35.02 \pm 1.06$ & Kaladaho-3 & $27.77 \pm 1.95$ & $12.24 \pm 1.13$ \\
\hline Andharupara-6 & $27.79 \pm 2.13$ & $7.08 \pm 1.04$ & Kaladaho-4 & $22.90 \pm 2.01$ & $12.93 \pm 1.05$ \\
\hline Nayabil-1 & $33.67 \pm 2.05$ & $28.64 \pm 1.10$ & Kaladaho-5 & $25.85 \pm 2.06$ & $8.73 \pm 1.04$ \\
\hline Nayabil-2 & $27.77 \pm 2.06$ & $22.90 \pm 1.01$ & - & - & - \\
\hline Nayabil-3 & $25.71 \pm 1.96$ & $13.73 \pm 1.06$ & - & - & - \\
\hline Nayabil-4 & $29.78 \pm 1.99$ & $18.16 \pm 1.06$ & - & - & - \\
\hline Nayabil-5 & $92.41 \pm 2.23$ & $13.76 \pm 1.11$ & - & - & - \\
\hline Nayabil-6 & $35.57 \pm 2.28$ & $6.05 \pm 1.02$ & - & - & - \\
\hline
\end{tabular}

Data are means \pm standard deviation of three replicates

\section{Conclusions}

The physico-chemical analysis of the present study revealed that all the soil samples of Nalitabari (Northern and Eastern Piedmont Plain) and Fulbaria (Madhupur Tract) location were very strongly acidic to strongly acidic in nature. Therefore, these soils should be managed properly by addition of lime based on calculation for suitable crop production. Among the essential nutrient elements found in the samples, the organic $\mathrm{C}$ content was low to medium, total $\mathrm{N}$ content was very low to low, the available $\mathrm{P}$ status was very low to optimum, the exchangeable $\mathrm{K}$ status was mostly very low and available $\mathrm{S}$ status was very low to medium. For successful agricultural production, proper management of soils, fertilizers and crops is of utmost importance and therefore, the soils with low nutrient status need to be fertilized in balanced with chemical fertilizers and organic manures based on the test values. However, the soil test values further need to be verified with crop response studies and soils should be tested on a regular basis to evaluate its present condition.

\section{Acknowledgement}

The authors acknowledge the partial support of Bangladesh Agricultural Research Council (BARC) through competitive research grant (CRG) of National Agricultural Technology Program-Phase II (NATP-II) for conducting this research work.

\section{Conflict of interest}

None to declare.

\section{References}

Bouyoucos GJ, 1962. Hydrometer method improved for making particle size analysis of soil. Soc. Agro. J., 54: 465-466.

Brammer H, 1996. The Geography of the Soils of Bangladesh. The University Press Ltd.,Dhaka 
Bremner JM and CS Mulvaney, 1982. Nitrogen-total. In: Page AL, RH Miller RH, DR Keeney (eds.) Methods of soil analysis: Part 2. American Society of Agronomy, Inc., Madison, pp. 595-624.

FAO-UNDP, 1988. Land Resources Appraisal of Bangladesh for Agricultural Development. Report 2. Agroecological Regions of Bangladesh, BGD/81/035.

FRG (Fertilizer Recommendation Guide), 2018. Fertilizer Recommendation Guide- 2012. Bangladesh Agricultural Research Council, Farmgate, Dhaka.

Hart JM, DM Sullivan, NP Anderson, AG Hulting, DA Horneck and NW Christensen, 2013. Soil Acidity in Oregon: Understanding and Using Concept for Crop Production EM 9061. OSU Extension. Corvallis, OR. $22 \mathrm{p}$.

Huq SMI and JUM Shoaib, 2013. The Soils of Bangladesh, world soils book series. Springer, Dordrecht.

Islam MA, MA Hasan and MA Farukh, 2017. Application of GIS in general soil mapping of Bangladesh. J. Geogr. Inf. Syst., 9: 604-621.

Islam MS, 2008. Soil fertility history, present status and future scenario in Bangladesh. Bangladesh J. Agric. Environ., 4 (Special Issue): 129-151.

Islam R, L Rahman, D Isam, A Kashem, A Sattar, SM Bokhtiar, B Hossain and M Rahman, 2018. Assessment of carbon stock and nutrient contents in soils of Northern and Eastern Piedmont plains of Bangladesh. SAARC J. Agri., 16: 61-72.

Jackson ML, 1973. Soil Chemical Analysis. Prentice Hall of India Pvt. Ltd., New Delhi, pp 69-182.

Knudsen D, GA Peterson and PF Pratt, 1982. Lithium, sodium and potassium. In: Page AL, Miller RH and DR Keeney (eds.). Methods of soil analysis: part 2. American Society of Agronomy, Inc., Madison, pp 225-245.

Kumar U, H Rashid, NH Tithi and MY Mia, 2019. Status of soil properties in relationship with soil pH in Madhupur tract of Tangail district in Bangladesh. Progress. Agric., 30: 282-287.

Moslehuddin AZM, S Laizoo and K Egashira, 1997. Fertility status of Bangladesh soils- A review. J. Fac. Agr., Kyushu Univ. 41(3.4): 257-267.

Olsen SR, CU Cole, FS Watanabe and LA Dean, 1954. Estimation of available phosphorus in soil by extraction with sodium bicarbonate. Circular No. 939, USDA, Washington.

Portch S, and MS Islam, 1984. Nutrient status of some of the more important agricultural soils of Bangladesh. In: Proceedings of International Symposium on Soil Test Crop Response Studies, Bangladesh Agricultural Research Council and Soil Science Society of Bangladesh, pp. 97-106.

Reddy CHBR and KS Subramanian, 2016. Synthesis and characterization of nano-amendment for effective remediation of soil acidity. Asian J. Soil. Sci., 11(1): 51-57.

Russel DF, 1986. MSTAT-C package programme. Crop and Soil Science, Department, Michigan State University, USA.

Saheed SM, 1984. Soils of Bangladesh. In: Soil Test Crop Response Correlation Studies.

Mannan MA, Habibullah AKM and Portch S (ed.), Bangladesh Agricultural Research Council and Soil Science Society of Bangladesh, Dhaka (Bangladesh), pp. 107-129.

Shil NC, MA Saleque, MR Islam and M Jahiruddin, 2016. Soil fertility status of some of the intensive crop growing areas under major agro-ecological zones of Bangladesh. Bangladesh J. Agril. Res., 41(4): 735-757.

SRDI (Soil Resource Development Institute), 2010. Land and Soil Statistical Appraisal Book of Bangladesh. Soil Resource Development Institute, Dhaka.

Walkey AJ and AI Black, 1934. Estimation of organic carbon by chromic acid titration method. J. Soil Sci., 25: 259-260.

Williams CH and A Steinbergs, 1959. Soil sulphur fractions as chemical indices of available sulphur in some Australian soils. Aust. J. Agric. Res., 10: 340-352. 